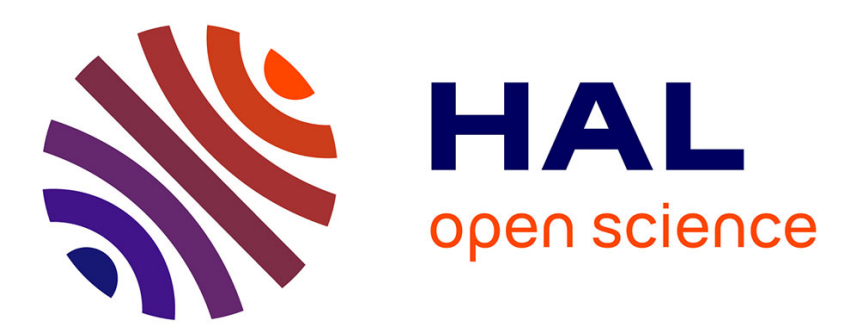

\title{
Societal deliberation on genetically modified maize in southern Africa: the debateness and publicness of the Zambian national consultation on genetically modified maize food aid in 2002
}

Pascal Newbourne Mwale

\section{To cite this version:}

Pascal Newbourne Mwale. Societal deliberation on genetically modified maize in southern Africa: the debateness and publicness of the Zambian national consultation on genetically modified maize food aid in 2002. Public Understanding of Science, 2006, 15 (1), pp.89-102. 10.1177/0963662506058386 .

hal-00571081

\section{HAL Id: hal-00571081 \\ https://hal.science/hal-00571081}

Submitted on 1 Mar 2011

HAL is a multi-disciplinary open access archive for the deposit and dissemination of scientific research documents, whether they are published or not. The documents may come from teaching and research institutions in France or abroad, or from public or private research centers.
L'archive ouverte pluridisciplinaire HAL, est destinée au dépôt et à la diffusion de documents scientifiques de niveau recherche, publiés ou non, émanant des établissements d'enseignement et de recherche français ou étrangers, des laboratoires publics ou privés. 


\title{
Societal deliberation on genetically modified maize in southern Africa: the debateness and publicness of the Zambian national consultation on genetically modified maize food aid in 2002
}

\author{
Pascal Newbourne Mwale
}

In the 2001/2002 farming season, southern Africa faced acute hunger. According to UN WFP/FAO statistics, about 14 million people were on the verge of death by starvation in the region. In Zambia alone, the UN WFP/ FAO estimated that about 3 million people were threatened with serious food shortages, and they would need about 630000 metric tons of food. The UN WFP offered genetically modified (GM) maize grain, procured from the US, to various countries in the region, including Zambia. A significant debate emerged around the question of US-produced GM maize grain in the region. This regional debate around the question of GM maize was most probably aroused by the issues raised by the Zambian case. The form of this debate and the issues driving its dynamics, are interesting both in themselves and also because they reveal something about the form by which public biotechnological debate, or public controversy on biotechnology, takes in public domains. This paper is an experimental intellectual exercise, an attempt at a conceptual analysis of "public debate" as a derivative, but quintessential, concept within what is broadly conceived of as public understanding of science. Thus, this conceptual analysis is an attempt at a prolegomena for, i.e. a preparatory conceptual approach to, our understanding better what public debate on science is and how it works in practice.

\section{Introduction}

Public debate about genetically modified foods (GMFs) has emerged in southern Africa involving various enclaves such as scientists, politicians, civil society organizations, traditional leaders, media personnel, among others. Scholarship on the question of the "conditions of existence" of such public debate is scanty. It is unclear what public debate is and how it works in reality. Using the case of the Zambian national consultation on genetically modified maize food aid (2002), I conceptually analyze "public debate." Debate emerges when there is ample room for persistent and sometimes profound disagreement in perceptions, beliefs, and attitudes between individuals or groups of people, most often 
arising from conflict, or divergence, of interests or principles about certain aspects of an issue or a set of issues. Debate becomes "public"-i.e. public debate-when there is a conscious or deliberate attempt by interlocutors to conduct or carry out the debate, via one or more mediating mechanisms, into an "open forum"- available and accessible to fellow interlocutor(s) - in which dialogic, or, better still, discursively interactive communication is evoked, or provoked, directly or indirectly.

\section{Methodological considerations}

This paper proceeds by way of conceptual analysis, drawing on some aspects of thematic content analysis, and using print news media texts. To identify my print news media sources for the material of this paper, I used three World Wide Web search engines, namely, http:/ /www.google.com, http://www.scholar.google.com, and http://www.yahoo.com. The majority of the sources were archived in various global, continental and regional websites such as http://www.allAfrica.com, http://www.gene.ch/genet.html, and http://www.irinnews.org. They were for the most part articles from two daily newspapers: The Post (Lusaka) and The Times of Zambia (Ndola). The selected dailies covered the debate in the broad and the specific sense, capturing a wide range of issues from the scientific to moral to political to economic to emotional; that is, complex issues arising from the possible adoption and use of genetic modification technology and its most notable products. The articles demonstrated a clear sense of addressability, that is, who the addressers and addressees were; what the modes of address and the issues at stake were. Upon a close reading and rereading of the selected articles, I embarked on conceptual analysis, together with low-level thematic content analysis (see, for example, Boyatzis, 1998: 53). Nevertheless, given the conceptualanalytical commitments of this paper, I hereby present only a summary of the findings from my thematic reading of the relevant texts in the two dailies.

Why the media as a source of research material? I think that in a study of forms of circulation and processes of transformation of texts of debate in the public domain, such as this one, media sources are as relevant as any other sources of research material. The message that circulates through the media is much closer to popular thought and imagination than it is to scientific thought. The media act as vehicles of beliefs, perceptions and attitudes of both experts and "lay publics." The media have immense power and influence over people's worldviews, for example, in the formation and transformation of their beliefs, perceptions and attitudes. The media lay a strong claim to defining "truth" and "reality." The message of the media relates closely to practical or social reality in both content and form. The media invoke a "moral vision" of the facts they report on, as sanctioned by a real or socially imagined "order of moral existence" (Ettema and Glasser, 1998: 100-1). Importantly, the media claim consistently and strongly to work for "public interest," representing a wider society—a "general public" (Darton, 2000; Ozouf, 1988). The powerful—for example the political and social elite-demonstrate their power through the media; thus, the media can and do operate as the chief defender, or the most vocal critic, of the powerful and the dominant (Shoemaker and Reese, 1996).

\section{The Zambian national consultation on GM maize food aid in context}

Drought-prone Zambia experienced serious food shortages in the 2001/2002 season when the drought was prolonged. In response to the food crisis the United Nations (UN) World Food Programme (WFP) offered Zambia food in the form of maize. It was then reported that 
some of the relief maize, especially that from the United States, was genetically modified (GM) maize, and the WFP confirmed this report. The WFP reportedly argued that it was not in a position to offer Zambia non-GM maize because the US, the major donor of the maize to the WFP, did not customarily segregate non-GM maize from GM maize.

Although some countries such as Malawi, Mozambique and Zimbabwe accepted the GM maize aid from the US, Zambia rejected it, fearing damage to human health and the environment, as well as unfavourable consequences on Zambia's international trade and commerce and on small to medium scale food crop farming. Before it made its decision, the Zambian government organized a national consultation-nation-wide, open debate-on whether or not it should accept the US GM maize aid. It also sent abroad (e.g. to the US, South Africa, the UK, Denmark, Norway) a fact-finding mission of scientists to learn whether or not GMFs like GM maize were safe for human health. The mission comprised local scientists led by Dr. M.M. Lewanika of Zambia's National Institute of Scientific and Industrial Research. The nation-wide, public debate involved meetings, interactive radio and television programs and newspaper articles as well as readers' letters to newspaper editors. Consequently, the government based its decision on the recommendations from the national consultation and a verbal report of the fact-finding mission of scientists to reject the USproduced maize.

The print media covered the national consultation, an exercise carried out mainly by the pro-government paper, The Times of Zambia and by the privately owned paper, The Post. (Other print media that reported on this public debate included the Pan African News Agency (PANA), Agence-France Presse-Associated Press of Canada (SAPA-AFP), UN Integrated Regional Information Networks (IRIN), Reuters, the Economist, The Sunday Times, Mail and Guardian, Business News, Zamnet News, Guardian, BBC News, and ISIS.) Between them, The Times of Zambia and The Post carried close to a total of 30 news stories on this public debate on GM maize in the period March to November 2002.

Of note, The Times of Zambia carried only five of the 30 or so news stories, giving one the impression that this pro-government paper deliberately imposed a blackout on the issue or it did not find the issue newsworthy (of news value) and hence its apparent scant regard of the issue. The Post's coverage of the public debate ranged far and wide, for example, from reports on and critical analyses of views and comments of key representatives of science societies (University of Zambia scientists like Dr. L. Mumba and Dr. M.M. Lewanika), UN agencies like the WFP and FAO, religious organizations like the Jesuit Centre for Theological Reflection (JCTR), the Zambian presidency, the Zambian political opposition, the European Union, and the US government.

By contrast, The Times of Zambia did not carry any substantial news stories, say, in the form of comments from newsreaders, or any substantial expositions and critical analyses of the issue. Not surprisingly, its report was nothing more than an uncritical partisan voice, offering blind support for the government anti-GM position. Nevertheless, The Post could not have been fully immune from ideological bias and polemics. Some critics saw The Post's wide coverage of the public debate as only apparent. For example, Dr. M.M. Lewanika argued that the media misrepresented the position of both the government and the donor community. For Lewanika, the media were rash to paint the Zambian government as having rejected the US-produced GM maize food that was being offered by the UN WFP because the government was under pressure from the Green movements embodied, or manifested, in the European Union, which was alleged to have strong trade and commercial interests with Zambia for non-GM maize food and other nonGM food products produced in Europe; or the government was allegedly under extra pressure from local, regional or international biotechnology activists or lobbyists such as 
non-governmental organizations like Biowatch, Geneworld, Greenpeace International, and GM Watch (Lewanika, 2004: 2-3).

The US itself was accused (by both government and other stakeholders) of trampling upon the "dignity" of Zambians by foisting GM maize down the throats of these famished Zambians when it could have very well afforded to donate non-GM maize (Lewanika, 2004). Moreover, the US was known to produce only 30 percent GM maize, and so, contrary to the then prevailing global expert opinion, the US was seen, especially by Zambian scientists, to be capable of segregating GM maize from non-GM maize (Lewanika, 2004). Therefore, Zambia's print media could not have been fully immune from ideological bias and polemics; their reportage and commentary were bound to manifest ideological elements underpinning positions of various stakeholders caught up in the cross-fire of positivist, technological development approaches and human health and bioethical as well as environmentalist concerns, a situation complicated further by the enigmatic interplay of imperialist forces and the manipulative and coercive power of global capital over national or regional capital. Worries about the media's misrepresentation of issues notwithstanding, the media were important in the circulation and transformation of the texts of public debate on GM maize in Zambia because, firstly, they highlighted ideological elements of interest groups in the public debate and, secondly, they attempted to explain what was to be popularly believed to be the truth and reality-thereby defining and reinforcing specific scientific, quasiscientific and moral visions-about biotechnology.

\section{The debateness of the Zambian national consultation on GM maize food aid}

Biotechnology is controversial in public domains because it is based on genetics, which is itself embroiled in controversy. An arena of public debate emerges around biotechnology worldwide. Societal deliberation on issues arising from biotechnology is evidenced in most parts of Africa, the southern African region included. Societal deliberation broadly covers interactive communication or discursive exchange of views on issues of general concern or interest. To this end, societal deliberation can take several forms such as talking, consulting, conversing, reading, writing, listening, or visualizing. This entails that each communication form has a mode of addressability that generates or at least expects a response from the (real or imagined) addressee, or else all we have is monologue. Societal deliberation occurs in several domains such as village or area development committees, town councils, city assemblies, theatre, film, radio, television, newspapers, or music. The criterion here is "interaction" or "exchange."

I hereby propose "public debate" as a special type of societal deliberation, in which, I think, the element of "interaction" or "exchange" is taken to an impossibly high level of conceptual rigor, rendering the concept vacuous and programmatically useless for theorizing about what is broadly schematized as public understanding of science. The overarching question then becomes: what are the conditions of existence of public debate on biotechnology in southern African societies? Or, more to the point: how is public debate on biotechnology possible at our societal level?

To avoid theorizing in a social vacuum, with unbounded scope and generality and other entrapments, I isolate and examine critically-for purposes of conceptual clarification-a claim made by a prominent Zambian biochemist and one time state presidential scientific advisor, Dr. M.M. Lewanika (2004). Lewanika claims that the "national consultation culminated into a national public debate" (Lewanika, 2004: 2). At a conceptual level, an argument can be raised whether or not the Zambian "national consultation" on GM maize 
food aid actually culminated into a national "public debate." An assessment of this argument should illumine or enlighten us about the conceptual quagmire in which the concept "public debate" is swamped and how this obscurantism blurs our vision of public understanding of science in this region. Moreover, this assessment has the potential to tell us something novel about the form(s) of this debate, and the issues driving its dynamics. This is interesting both in itself and also because it reveals something about the form by which public biotechnological debate, or public controversy on biotechnology, takes in public domains. Let us bear in mind the bifurcation in the argument: debateness and publicness.

\section{Did the Zambian national consultation become a debate?}

The first fork of the argument can be assessed in line with Lewanika's claim that the national consultation culminated into a national public debate. The "debateness" problem invites a basic question: what makes debate "debate"? But, first, there is the problem of author-intention: why does Lewanika not just leave the national consultation simply as a "consultation"- why the conceptual intensification of "consultation" to "debate"? Presumably, the author has reasonable grounds for construing a conceptual shift from "consultation" to "debate." Let us scrutinize this conceptual shift, initially, referring to the lexicon. Lexically, to "culminate" (from Latin culmen: summit) is "to bring to the point of greatest intensity or climax"; it also denotes "to give form or shape."

So, Lewanika is at no point unclear about the "original" nature of the societal deliberation; it was a consultation. The government was consulting its subjects about a decision it was about to make: to accept or reject the UN WFP's offer of the US-produced GM maize food. The "consultation" shifted to "debate" (only) towards the end. What are Lewanika's premises in his claim about this climactical shift of the national consultation to a public debate? First, the national consultation drew on society-wide representation. It involved citizens and traditional leaders, state bureaucrats (for example, Secretary to Cabinet, the Chair), politicians, academics, foreign missions, public science institutions, members of parliament, scientists, university lecturers, senior civil servants, representatives of local and international non-governmental organizations, representatives of diplomatic corps, representatives of donors, and two government ministers (Lewanika, 2004: 2).

The notion at play here is that of "nation" as a "popular public," or what Warner calls a "social totality" (Warner, 2002: 65). Second, the national consultation was deliberative (talk-centric and participatory) in that it was organized in various forms including meetings (discursive exchanges), interactive radio and television programs and newspaper articles as well as readers' letters to newspaper editors (Lewanika, 2004: 2). In short, the national consultation was societal and deliberative, thereby satisfying the requirement of societal deliberation: communicative interaction or discursive exchange. Thus, it can be safely argued that the national consultation was a genre of societal deliberation. But, in spite of all this, did the national consultation become a public debate? Skeptics give us a hard nut to crack here.

Let us look closely at the possible horns of dilemma, as exposed by our skeptics. We are further told that this apparently nation-wide representation gave "an overwhelming majority" saying no to the GM maize food aid (Lewanika, 2004). Apparently, there were a few dissenting voices; Lewanika observes, "Only a couple of participants spoke in favour of accepting the GE [genetically engineered] Food Aid" (Lewanika, 2004: 2, my emphasis). The national consultation lasted two months (July to August 2002). Given this apparently great unanimity, leading to the widest possible degree of consensus, our skeptics can tempt us to deduce that during this long period of societal deliberation there was little or no debate. 
Lexically, to "consult" is not necessarily to "debate," our skeptics would be quick to point out. The conventional denotation of the term "consult" (from Latin consultare: to take counsel) is "to seek advice or information," or "to refer to." Another denotation of "consult," that is the closest to "debate," is "to exchange views; to confer." Let us adopt the second denotation of "consult: to exchange views or confer," and then envisage the possibility that societal deliberation on GM maize food aid involved some sort of discursive exchange of views, or conferring; our skeptics would still suspect us of stretching the point in according this exchange of views, or conferring, the status of debate.

Our skeptics would further argue that conceptual-lexically, in a formal debate, debaters (contenders or contesters) take turns in presenting their respective arguments, identifying weak points in each other's arguments and presenting counter claims (counter conclusions) to challenge each other's claims (conclusions). The aim is to convince the audience and other debaters that one's argument is more cogent, i.e. it is an argument whose conclusionclaim-is based on sounder and stronger premises (Conceptual Dictionary, 1994: 59). In the Zambian case, our skeptics would complain, we are not informed about the bone of contention or the central issues of contestation, or intricacies of arguments vis-a-vis the national consultation. Instead, we are presented with an official addresser-the stateseeking nationalistic legitimacy for its political decision by appealing to the social totality of "nation." For our skeptics, this social totality can be perceived as a single, all-encompassing "false we," that is, a totalizing collectivity that soliloquizes with itself, thereby generating and sustaining itself on naive unanimity, peremptorily yielding pseudo-consensus on a complex issue that would otherwise have generated controversy in Zambian society.

If we were to fall prey to snares of our skeptics so as to be made to insist dogmatically, as they do, that debateness must have the characteristic mark of persistent and profound disagreement among stakeholders, then we would be driven to the conclusion that the national consultation did not culminate into a public debate. In reading with, rather than against them (the skeptics), we would find ourselves dismissing the Zambian national consultation, as a process of consultation by a government, which appealed to a social totality in order to endorse its plainly political decision. But, this conclusion would be hasty.

Why would this conclusion be hasty? In general, what are the blind spots in the premises in the argument that leads to this hasty conclusion? Firstly, the lexical definition is restrictive. Apparent great unanimity on an issue does not preclude debate. Debate can lead to greater agreement even on a controversial issue. Secondly, we can question the formalistic-rationalistic axioms of debate. The theoretical legacy of the concept "debate" is usually identified with the Project of Critique. There are serious conceptual difficulties in either representing or not representing societal deliberations like the Zambian national consultation as a debate. ${ }^{1}$ According to Schrag, it is not uncommon today to hear people talk derisively of "the poverty of reason," "the bankruptcy of the logos," or, catastrophically, about "the end of philosophy" (Schrag, 1994: 61). This contemporary "war on reason" is more conspicuous and more ferocious in "postmodernism," where, despite its plurality of orientations, the problematization of rationality is one of the recurring themes. Indeed, for Schrag, "the postmodern celebration of plurality, multiplicity, heterogeneity, paralogy, and incommensurability makes the task of finding a place for the claims of reason particularly demanding" (Schrag, 1994: 61).

In contemporary Anglo-American political philosophy, Rawls's project of political liberalism (Rawls, 1993), which is grounded in the ideal of rationality (as reasonableness) faces challenges not necessarily from postmodernism but from multiculturalism, or similar theories about cultural diversity. Rawls's public reasonability—a complicated and yet 
crucial civic virtue - always requires liberal-minded people especially in a multicultural or culturally diverse polity to give reasons to different others for their demands in ways that they can understand and accept as reasonable. For Rawls, people should avoid simply stating their preferences and interests or making threats. People's reasons must be public, implying that their reasons should be capable of being understood and accepted by fellow citizens who hold different background beliefs, perceptions and attitudes-comprehensive worldviews such as religious, moral and philosophical doctrines - consistent with their status as free and equal citizens. The civic virtue of public reasonableness is complicated for it demands patience and tolerance as it usually involves listening to what one would (at least on the face of it) perceive as strange, appalling, and sometimes obnoxious views from "different others" as in a multicultural polity (for example, see Kymlicka, 2002: 289), among "other complications" 2 that tend to be raised by "demands" of the civic virtue of "public reasonability" or "public discourse."

In spite of this skepticism about reason, especially in contemporary postmodernist and multiculturalist discourses, modern humankind still uses and capitalizes on the ideals and value-claims of the Enlightenment, such as reason. People's motives and thoughts, as well as thought-acts, are still informed, illumined and guided by ideals and value-claims that were the archetype of the period of the Enlightenment. For example, Peperzak (1994) cites Enlightenment ideals and value-claims which are still held dearly today. ${ }^{3}$

Therefore, debate is possible and often a necessity in societal decision-making, especially on issues that are controversial, and conflict-ridden. What remain contentious and contestable are the conditions of the existence of debate itself. ${ }^{4}$ To attribute or not to attribute the quasi-utopian quality of debateness to the Zambian national consultation is not the quintessential question here. Rather, the quintessential question is whether or not there was at the time some degree of communicative interaction or discursive exchange of views on issues of general concern or interest-whether or not societal deliberation took place, that is, whether Zambians talked to one another about the GM maize food aid in question. And yet our skeptics would remain indefatigable; they would go on with their skepticism, this time doubting the publicness of the national consultation, and hence the second fork of the argument.

\section{The publicness of the Zambian national consultation on GM maize food aid in 2002}

In the theoretical orientation of Habermas et al., one of the assumptions about the conditions of the existence of "public debate" is that there exists a "public sphere" where citizens assemble to form a public body and where they deliberate (or confer or converse) and then publish their opinion in order to develop or shape public opinion on an issue or a set of issues. Public debate can lead to public opinion formation, and, sometimes, to decision- and policy-making. Theorists of the public sphere, especially those who directly engage critically with Habermas (1989) such as Fraser (1993) and Eley (1993) are unequivocal about the dialogic or interactive nature of people's communication in open forums. On the large question of the "mediating" instrument of the media—as a communicative vehicle of public debate - the role of the media is considerable. On this, Eley cites Habermas; for Eley, Habermas admits, "Today newspapers and magazines, radio and TV are the media of the public sphere" (Habermas, 1974: 49).

But, the Habermasque orientation would only enable me to identify one broad type of public debate on GM maize in Zambia: physically organized public debate. Public debate 
can also be conceived in a different way from that of a concrete audience, or a social totality, where deliberators or interlocutors assemble to constitute a physically identifiable public body for public opinion formation or decision-making. The work of Warner (2002) sets the theoretical stage for this alternative reading of public debate. In the first-Habermasiansense, we have a "physically organized" public debate, which is localized, dialogical and close-ended. In the second-Warnerian—sense, we haved a "mediatized" public debate, which is non-localized, non-dialogical and open-ended.

Warner's notion of " $a$ public" as formed and constituted by the reflexive circulation of discourse-via a "concatenation" of texts-does not require publics to be consciously or deliberately organized, to be arranged in concrete space and time, and to be constituted by members who are connected or familiar to each other. For Warner, publics can be formed and constituted by [a] circulating [concatenation of] texts. It is thus conceivable to explore public debate on GM maize in Zambia—and elsewhere-by studying circulating texts. To articulate how textual "reflexive circulation" works, especially how it enables the transformation of texts in public domains, Warner constructs interesting links between public, text, and discourse. It is the addressability of discourse that enables me to identify addressers and addressees in the texts of public debate on GM maize in Zambia. Texts inhabit discourse for the very reason that people inhabit discourse. Let me now put Warner's ideas in our context.

\section{Popular publics and text (or discourse) publics}

We are told that the report that was sent to the government on the national consultation presented the latter as a national public debate. Lewanika remarks:

A subsequent report of the national public debate on GE foods recommended that the Zambian government should not accept GE food aid. The Zambian government studied the report of the national public debate on GE and the recommendation that emanated from it. (Lewanika, 2004: 2-3, my emphasis)

I would like to isolate and conceptually analyze "public debate" from Lewanika's remark. It would appear that Lewanika's remark does not stand any chance conceptually. The notion of "public" as a "popular public," for example, a nation would be unpalatable for our skeptics. To marshal their critique against Lewanika et al., our skeptics would summon the views of "revolutionist" thinkers like Habermas ${ }^{5}$ (1989) and, especially Warner (2002) in contemporary studies on public intellectual life.

Warner's notion of counterpublics as subaltern discourse publics or as alternative power-domains for the voice of protest and resistance against the status quo provides our skeptics with additional ammunition. Warner's notion of "a public" as a "text public" would further complicate our social imaginariness of publics of GM maize food aid in Zambia in 2002. For Warner, there can be an infinite number of publics (and counterpublics) within one social totality like the Zambian nation. A text public is "the kind of public that comes into being only in relation to texts and their circulation" (Warner, 2002: 66). The publicness of a text public is based on writing, speech, object, or performance. A public is not a crowd, or a concrete audience, or a group requiring co-presence. Physical space and physical presence and full participation are not the determinants of belonging to a public (Warner, 2002: 71). Circulation is fundamental to the constitution of text publics: "Without the idea of texts that can be picked up at different times and in different places by otherwise unrelated people, we would not imagine a public as an entity that embraces all the users of that text, whoever they might be" (Warner, 2002: 68). Publics are constituted by circulating texts, 
which is the same thing as saying discourse constitutes publics, and hence the inclusive disjunction "text or discourse publics."

Circulation has both notional and empirical aspects. Empirically, circulation deals with what is known about discourse publics which enables a scene of performativity or practical possibility. Notionally, circulation deals with the unknown about discourse publics which enables a scene of transformation. Circulation is not only inter-textual (or even intergeneric) but also temporal: for a text to have a public it must circulate through time; after all, conversation does not stop. Therefore, to confer agency on discourse publics is to promote misleading ideologizations and hence to entertain durable illusions (Warner, 2002: 90-1, 95). The reality of a public lies in its reflexivity "by which an addressable object is conjured into being in order to enable the very discourse that gives its existence"; that is, a public must have some way of being addressed (addressability) in discourse (Warner, 2002: 97).

A text public is "strange" in that it is hidden from view. The strangeness of a public allows us to think of discourse not as a people and not as an actually existing set of potentially numerable humans. What is quintessential in the definition of "text public" is its self-organizing ability. Self-organization entails independence or autonomy from the state, laws, formal frameworks of citizenship such as voter participation in general elections, or preexisting institutions like the church. The self-organization nature of publics through discourse enables them to produce a sense of belonging and activity. Participation, no matter how minimal, in discourse is pointless if a public is powerless and if its deliberations do not translate into action. Thus, the addressability of discourse publics faces two challenges, namely, comprehension and action because "often one cannot imagine addressing a public capable of comprehension or action" (Warner, 2002: 69). A discoursing public must be organized by something other than the state. An independent public is sovereign with respect to the state together with its political and bureaucratic apparatuses.

Moreover, in addition to its self-organizing ability, a text public is self-creating because a public is a space of discourse created and organized by discourse: "publics do not exist apart from discourse that addresses them" (Warner, 2002: 72). This makes publics strange 7 entities, especially their antipathetic position against the state and the ideological machinery. And yet the state can have intellectual agency that is crucially useful in regard to policymaking, regulation and resource mobilization vis-a-vis biotechnology. Although this sort of antipathy is espoused usually as a bulwark against totalitarianism and hence the authoritarian and patronizing tendencies of states, I think that effective and powerful public discourse, for example, public debate on GMFs, need not presuppose total independence of a discoursing public from the state machinery. Some publics that engage in discourse on GMFs can be state-organized; they can have political or polemical agency. Therefore, Warner's apparent antipathy to the state dis-empowers and paralyzes his "publics," and to some extent his "counterpublics."

\section{Are publics to be seen as enclaves necessarily poised against the state?}

Although Fraser's appeal to social totalities like national parliaments as embodiments of "strong publics" (Fraser, 1993) essentially legitimates majoritarianism typical of popular democracies, she cautions us against the temptation to debunk the whole idea of states' "political public spheres" as Habermas and Warner do. We can doubt Fraser's belief in parliamentary sovereignties as "strong publics" due to concerns about the "fairness and free-ness" of electoral processes, in that parliaments are formed through majority vote, and are a result of populism. According to Furedi (2004), electoral participation-through 
voting - in popular democracies is the pretence of participation; it is a commercialized form of social inclusion.

Nowadays, the act of democratic voting is subordinated to the objective of retaining contact with people so that ultimately "contemporary populism has no wider purpose than to connect with people" and hence "institutions are less likely to be judged according to criteria internal to themselves than on their relevance and accessibility to a wider public" (Furedi, 2004: 92-3). Parliamentarians seek their legitimacy, and mandate to make authoritative decisions, from popular publics who elect them into parliament. Popular publics can be in the form of either a social totality (the public of a polity like nation or people in general) or a concrete audience (a totality that is bounded by an event or physical space) (Warner, 2002: 65-6). But, in spite of all this, the antipathy against states' "political public spheres," such as the Zambian national consultation, seems misplaced for the very reason that representativeness (publicness) and rigor and critical effectiveness (debateness) of societal deliberations, do not necessarily require attenuating, or debunking, the idea of the state.

\section{Conclusion}

There is little doubt that societal deliberation on GM maize food aid did take place in Zambia, in the form of a national consultation. By contrast, the decision by Malawi, Zimbabwe and Mozambique to accept the UN WFP GM maize food aid was made only at state or government level. The people of these three countries were not consulted on the matter. None of these three governments conducted even a public opinion survey on the UN WFP GM maize food aid. By conducting a national consultation on a controversial scientific issue, the Zambian government took a unique step towards deliberative democratic decisionmaking: it provided an open forum for society to deliberate on an issue of wider concern.

And yet, given the conceptual quagmire in which the concept public debate is swamped, there are no straightforward, discrete answers to the question: was it a public debate? If public debate were conceived exclusively using the Habermasque blueprint of rational-critical debate, or the Warnerian model of counterpublics' oppositionality to the status quo (e.g. gay and lesbian and ethnocultural minority movements), then the Zambian national consultation case would not satisfy this rigorous demand. Nevertheless, to argue that the Zambian nation could not have debated about GM maize because it did not understand, or was not even aware of, biotechnology is to subscribe uncritically to the deficit model which is open to question. ${ }^{8}$ Qua the deficit model, one stands in danger of charging the Zambian nation with "scientific illiteracy"- a subtle form of epistemological imperialism.

There are, however, (not so convincing) reasons that might tempt some people to think so dangerously. As regards pockets of evidence of public "ignorance" about biotechnology as such, one need not go very far into the past in Zambia. In 2001, only a year before the national consultation was conducted, two Zambian scientists reported that societal awareness about biotechnology was "just beginning" and "disappointingly low" in Zambia (Chinsembu and Kambikambi, 2001: 13-14). The education system was poor; there were no courses on biotechnology even at university level. "Scientific illiteracy" was high. People lacked interest in scientific issues. The agricultural extension system did not have the capacity and trained personnel to update farmers on latest developments in agricultural biotechnology: "many farmers knew little about GMOs and saw them as 'bugs' or 'monsters' that could have serious effects on those who consumed them" (Chinsembu and Kambikambi, 2001: 15). 
There were no avenues for scientists to disseminate information to the people. People, including farmers, were ignorant of biotechnology: "A radio talk show just revealed that the public is essentially ignorant about current issues that underpin the use of biotechnology in agriculture" (Chinsembu and Kambikambi, 2001: 13). The media in general lacked access to reliable information. The Internet was unreliable or nonexistent even for media personnel working in major national news organizations. The language of biotechnology was unknown to the media. Zambia had no policy or regulations on genetic modification technology. It had no capacity to assess GMFs in particular or living modified organisms (LMOs) in general, for example, in terms of possible pollution of the environment or contamination of non-GM crops. Also coincidentally, the food crisis was preceded by general elections and hence the focus of the attention of the media on the general elections, especially the presidential polls.

So, qua the deficit model, given this dismal and poor state of affairs in terms of knowledge and awareness about biotechnology as reported in 2001, the Zambian nation could not have been prepared and competent enough to engage in a rigorous public debate only a year later in $2002 .{ }^{9}$ But, as pointed out earlier, this line of thinking amounts to imposing the charge of "scientific illiteracy" on the Zambian nation.

The charge of "scientific illiteracy" on the Zambian nation is preposterous and empty mainly because, once more, it is a form of epistemological imperialism, and that, theoretically speaking; it oversimplifies the public knowledge-attitude nexus. For example, in the Euro-American cluster, increasing "scientific literacy" about GMFs in particular or LMOs in general has not necessarily led to greater public support for these new biotechnological innovations and their products. To the contrary, public opposition to GMFs remains fierce in what are generally considered as "scientifically literate" regions of the globe such as northern Europe. Of course, we must acknowledge the "activist wedge" driving between popular thought and "unorthodox" science: the anti-GM activist voice is sometimes louder and sharper than that of the Euro citizenry. For example, Greenpeace International continues to draw swords against, and sometimes it triumphs over, multinational GM biotechnology companies like Monsanto. ${ }^{10,11}$

Be that as it may, ongoing research shows that the more knowledgeable people are about the new science, the more skeptical they become in respect to its innovations, that is, "better informed respondents tend to be among the most skeptical when it comes to 'morally contentious' and 'non-useful' sciences" (Evans and Durant cited in Sturgis and Allum, 2004: 59). Apart from the usual media hype and the propaganda and influence of anti-GM activist groups most often operating under the rubric of the Green movement, active public dislike for certain innovations and products of biotechnology cannot entirely be attributed to poor public understanding of biotechnology, or people's biotechnological illiteracy or lack of biotechnology education. As some recent "public attitudes" surveys conducted in the UK show, the relationship between public knowledge about biotechnology and public attitudes towards biotechnology is complex, and so, for the sake of intellectual honesty, this relationship warrants closer scrutiny. ${ }^{12}$

Finally, on the whole, I have argued that what is quintessential is societal deliberation, no matter whether we characterize this discursive practice as wholly or partly inclusive or exclusive of "public debate," for example, in the sense of Habermas et al. The definition of public debate is obviously in need of sharpening, and this will (partly) involve incorporating into it less formalistic and less rationalistic, as well as interactive and discursive, forms of societal deliberation on matters of general concern or interest, such as the most recent scientific advancements involving controversial biotechnological innovations in southern Africa. 


\section{Acknowledgements}

The author wishes to express his sincere and profound gratitude to his luminous mentors Professor Carolyn Hamilton and Dr. Susan Van Zyl, as well as the author's fellow doctoral research associates in the Constitution of Public Intellectual Life Research Project, in the University of the Witwatersrand, Johannesburg, South Africa, for their insightful and critical comments and advice during the conception of the preliminary draft of this paper.

\section{Notes}

1 Generally, the concept debate invokes quasi-utopian images of rational, critical and free societal deliberation, a communicative ethos that was archetypical of the Enlightenment. Indeed, today rationality is still by and large upheld as one of the basic conditions for the existence of debate. And yet it is far from clear what it means for debate to be "rational" today. This sort of skepticism about reason, at least in philosophical circles, can be traced back to Scottish philosopher David Hume (1711-1776). So the tale goes that Hume's skepticism about reason was so Pyrrhonistic that it influenced considerably Hume's younger contemporary across the English Channel, German philosopher Immanuel Kant (1724-1804). Arguing that reason is a slave of the passions (abstract of his A Treatise of Human Nature, 1739), Hume is alleged to have awakened Kant from his dogmatic slumber in the 1760s. Enmeshed as the youthful Kant was in the then prevailing Leibniz-Wolffian rationalism, Kant initially held a somewhat strong belief in the potency of reason. Kant's vindication of the claims of reason, which responds partly to Leibniz's quasi-religious belief in the potency of reason and partly to Hume's skepticism about reason, appears in his epoch-making Critique of Pure Reason (1781, revised 1787). Apparently, the question of rationality seems to have been abandoned to the vagaries of philosophical pastimes since the time of Kant. Skepticism about reason reached its climax in the (arguably Marxian) Frankfurt School (especially in the seminal works of major proponents of its critical social theory, namely, Theodor Adorno, Max Horkheimer and Herbert Marcuse) which put an irreparable dent on the quasi-utopian ideals and value-claims of the Project of Critique as propounded and championed zealously by Enlightenment thinkers like Kant. Rationality is undoubtedly linked closely with philosophy. Schrag discerns this link: "What does it mean to be rational? . . . To do philosophy, it has been assumed, is to put into play, in a variety of ways, the claims of reason; and to be a philosopher is to take on the mantle of the guardianship of rationality" (Schrag, 1994: 61). But, this apparent intimacy between rationality and philosophy is mutually risky to both partners; if one goes down so does the other. Kant's essay (An Answer to the Question: What is Enlightenment?, 1784) on public reason as personal courage to criticize authorities - in order for persons to escape from self-inflicted immaturity or self-imposed tutelage-is not very helpful here because, apart from its placing a high premium on the potency of reason, it is based on an un-argued, unarticulated, and hence dubious, assumption, namely, the private/public dichotomy. Thus, the portrait of the philosopher as the guardian of rationality and the putative claims of reason are susceptible to skeptics' ruthless attacks today.

2 Public reasonableness - at least the way in which Rawls (1993) seems to make it out to be-seems to pose other challenges in a multicultural polity. For example, it requires one to make a conscientious effort to distinguish private beliefs, perceptions and attitudes from those which are capable of public defense. It also seems to require one to try to distance oneself from one's own vantage point, as it were, and then look at issues from others' viewpoints, which, obviously, would be different from one's own comprehensive worldviews. In a multicultural polity it is hard to conceive what qualifies as "a public reason." After all, one may doubt the potency of public reasoning to adjudicate between conflicting principles and interests. The apparent impotency, or powerlessness, of public discourse requires theorists to go on vindicating public reasoning, given that Kantdriven arguments for the universality and objectivity of reason itself remain contestable. When all is said and done, is not public reasoning nothing but a publicity stunt for democratic societal deliberation, that is, a sheer exhibitionist compromise and accommodation of unresolved and irresolvable but disturbing and destabilizing differences - rather than rigorous, free and open debate for important and urgent issues?

3 Such as,

The recognition of human rights, emancipation of humans from imposed authorities, the rejection of discrimination, the claim of equal participation in political decisions, the veneration of reason and its universal laws, in short: the ideals of modern democracy proclaimed by the English, French and German philosophers of the 18th century, still are the basic principles on which we build our social and personal practice. (Peperzak, 1994: 456)

4 For example, why should debate always be rational-critical? What does rationality mean? What does critique mean? How do we mitigate the potentially or susceptibly divisive and disruptive forces of cultural diversity in 
our search for "greater democracy"? These questions are lingering against the background of well-intentioned liberal and deliberative democratic attempts to make societal decision-making practical, free, more inclusive and more deliberative.

5 In a nutshell, Habermas's historiography of 18th century Europe-especially France-commits him to identifying the sphere of rational-critical debate, not with the state's "political public sphere," but with the "private public sphere" of the bourgeoisie and civil society (Habermas, 1989: chapter 18). On a Habermasque reading, therefore, a state-organized consultation-a consultation under the aegis and patronage and agency of the state-lacks not only deliberative democratic value but also mass emancipatory potential.

6 Warner talks of the "autotelic circularity of discourse publics," implying the self-organizing, reflexive nature of publics. A text public is a kind of reflexivity in that it is a social space created by the reflexive circulation of discourse. Single texts do not create publics but the "concatenation of texts through time"-and so no single text, voice, genre, medium can form a public. Only when a previously existing discourse can be supposed and when a responding discourse can be postulated, can a text address a public, and the two texts are related socially. The relationship between the two texts is less argumentative and polemical than that which is readily imaginable via metaphors of conversation, answering, talking back; that is, public discourse encompasses the multi-generic life-world organized by a relational axis of utterance and response (Warner, 2002: 90-1, 95).

7 Apparently, Warner's notion of "strangeness" of publics makes participation difficult to construe. For Warner, a public is constituted through mere attention. Publics lack institutional being. They are virtual entities, and not voluntary associations. Since a public exists only by virtue of address, it predicates some level of attention, however notional, from its members. Attention is less about cognitive quality than the mere fact of "active uptake." Attention as active uptake is indispensable. For example, any member who becomes inattentive to a particular discourse ceases automatically to be a member of the discourse in question. Given that the threshold of belongingness to publics is attention-active uptake-publics can be understood within the conceptual framework of civil society, requiring free, voluntary, and active membership.

8 The deficit model assumes that non-expert people such as lay publics, activists, civil society organizations, and politicians are scientifically illiterate and hence they need science education. The deficit model aims to enhance scientific literacy by popularizing science through public information campaigns-by scientists—in order to remedy people's disenchantment with science (e.g. see Sturgis and Allum, 2004).

9 In the formal sense, there was general poverty of knowledge and information about biotechnology prior to the national consultation. Some "considerable discussion" did take place. But, this discussion appears to have been the prerogative of expert scientists, voicing concerns about GMFs. For example, some experts hoped GMF crops would redeem the "intensely poor" agriculture sector and revamp the "crises ridden agricultural economy," given that "small scale resource-poor farmers . . . produce over 80 per cent of the country's maize, the staple food crop." Since the liberalization of the economy in 1991 Zambia had not produced enough maize to satisfy its people's dietary demand. Unavoidably, Zambia was importing maize from such overseas countries as the USA, Canada and Argentina "where GM crops have already been commercialized." Liberalization of the market itself was a cause of concern among experts and political elites in Zambia because in the case of seed for genetically modified maize this liberalization rendered the local market exceedingly vulnerable to the monopoly and exploitation of foreign multinational seed companies, mostly from South Africa. But, these hopes and fears seem to have been entertained mostly by experts and political elites who had some rough idea of the impact of the latest developments in biotechnology. The few experts who were engaged in "considerable discussion" were concerned more about the economic repercussions of biotechnology. Although there are some dissenting voices amongst farmers exporting to the GM-free European market, most are more worried about the health of the market than the environment, biodiversity and health issues that have been raised in connection with GM crops in other parts of the world. . . Public debate about biotechnology that has swept other parts of the world has not yet hit Zambia (Chinsembu and Kambikambi, 2001: 14-15).

Greenpeace says Monsanto GM crop needs fresh data 16/02/2005-GM food ingredients under attack, again, this week as environmental group accuses Brussels of "exposing EU states" to risk from genetically modified corn. In a statement yesterday, Greenpeace claims the European Commission gave the green light to Monsanto's MON810 maize into the EU seed catalogue, without a "comprehensive monitoring plan." (www.foodqualitynews.com/news)

11 "Greenpeace blocks Monsanto's attempt to patent Indian Wheat.” Tuesday 27 January 2004, Germany/Munich (www.greenpeace.org/india_en/news).

12 The 2003 UEA-MORI UK Survey showed that $72 \%$ of British respondents knew that science makes life easier, that $80.6 \%$ of them knew that science contributes to human progress, and that $70 \%$ felt the need for scientific progress. But $69 \%$ held suspicion about science and $57 \%$ feared science carries more harms than benefits. Another 2003 UEA-MORI UK Survey on public attitude towards GM food and crops showed that of the 1363 British respondents, 53\% were ambivalent whether GM food should be promoted or opposed. Twenty-nine 
percent said GM food should be opposed; only $9 \%$ said GM food should be promoted. Fifty-six percent said they believed GM crops could benefit people in developing countries; $17 \%$ did not believe so, and $25 \%$ were unsure. See http://www.data-archive.ac.uk/doc/5027/mrdoc/pdf/5027userguide.pdf.

\section{References}

Boyatzis, R.E. (1998) Transforming Qualitative Information: Thematic Analysis and Code Development. London: SAGE.

Chinsembu, K. and Kambikambi, T. (2001) "Farmers' Perceptions and Expectations of Genetic Engineering in Zambia," Biotechnology and Development Monitor 47: 13-15.

Conceptual Dictionary (1994) London: Macmillan.

Darton, R. (2000) "An Early Information Society: News and the Media in Eighteenth Century Paris," American Historical Review 105(February): 1-35.

Eley, G. (1993) "Nations, Publics, and Political Cultures: Placing Habermas in the Nineteenth Century," in C. Calhoun (ed.) Habermas and the Public Sphere, pp. 287-339. Cambridge, MA: MIT Press.

Ettema, J. and Glasser, T. (1998) Custodians of Conscience: Investigative Journalism and Public Virtue. New York: Columbia University Press.

Fraser, N. (1993) "Rethinking the Public Sphere: A Contribution to the Critique of Actually Existing Democracy," in C. Calhoun (ed.) Habermas and the Public Sphere, pp. 109-42. Cambridge, MA: MIT Press.

Furedi, F. (2004) Where Have all the Intellectuals Gone? Confronting 21st Century Philistinism. London and New York: Continuum.

Habermas, J. (1974) “The Public Sphere,” New German Critique 3: 49 (cited in Eley, 1993).

Habermas, J. (1989) The Structural Transformation of the Public Sphere: an Inquiry into a Category of Bourgeois Society. Cambridge, MA: MIT Press.

Kymlicka, W. (2002) Contemporary Political Philosophy: an Introduction, 2nd edn. Oxford: Oxford University Press.

Lewanika, M.M. (2004) "Food Aid and Genetically Modified Organisms," Proceedings of Conference 2 on "Science and Democracy," University of Perugia, Naples, Italy. Available: http://www.dipmat.unipg.it/ $\sim$ mamone/sci-dem/nuocontri/mmlewanika.htm.

Ozouf, M. (1988) "Public Opinion at the End of the Old Regime," Journal of Modern History 60(Supplement): S1-S20.

Peperzak, A. (1994) "Ethics in our Time," in T.J. Stapleton (ed.) The Question of Hermeneutics, pp. 451-68. Dordrecht: Kluwer.

Rawls, J. (1993) Political Liberalism. New York: Columbia University Press.

Schrag, C.O. (1994) "Transversal Rationality," in T.J. Stapleton (ed.) The Question of Hermeneutics, pp. 61-78. Dordrecht: Kluwer.

Shoemaker, P.J. and Reese, S.D. (1996) Mediating the Message: Theories of Influences on Mass Media Content. London: Longman.

Sturgis, P. and Allum, N. (2004) "Science in Society: Re-evaluating the Deficit Model of Public Attitudes," Public Understanding of Science 13: 55-74.

Warner, M. (2002) Publics and Counterpublics. New York: Zed Books.

\section{Author}

Pascal Newbourne Mwale is a lecturer in Social and Political Philosophy, Philosophy of Science, Logic, and Ethics at Chancellor College, University of Malawi. Located in the multidisciplinary Constitution of Public Intellectual Life Research Project, he is currently pursuing his doctoral research on the social and political complexities of the nature and dynamics of public debate on genetically modified maize and reproductive human cloning in southern Africa at the University of the Witwatersrand, Johannesburg, South Africa. Correspondence: Graduate School for the Humanities, University of the Witwatersrand, P/B X3 Wits 2050, South Africa, e-mail: mwalep@webmail.co.za 